\section{ABSTRACT OF A CLINICAL LECTURE on}

\section{THE USE OF HAMMOCKS IN SURGICAL PRACTICE. Delivered Fune 12 th, 1875 .}

BY R I C H A R D D A V Y, F.R.C.S., Surgeon to the Westminster Hospital.

Gentlemen, - I introduce to your notice to-day Seydel's hammock, and wish to tell you the line of thought that has led me to employ it in surgical practice, and then to direct your attention to its more extended application. Two of these hammocks (a child's and an adult's) are now swung in this theatre; and the illustrated sheet gives you a general idea of their usefulness, as well as a description of their material, size, weight, price, etc. At the Surgical Aid Society, I have for the last year used hammocks for the treatment of spinal curvature, because it seemed to be a most excellent method of giving rest to the spinal column, and guarantees an immediate enforcement of hygienic conditions. Bad landlordism and good surgery are sworn enemies : how often are surgeons called to see a pitiable humpback crying in a dark corner of a squalid room, or sitting up, hands on knees, in some miserable tenement! Do not be misled by supposing that a steel machine can put this in order, but direct your attention particularly towards maintaining the spinal column at rest, adopt measures calculated to increase the patient's vigour, and pay not too much attention to the actual deformity. Now, think for a moment how Nature grants immunity from accident and rest to a spinal cord. Anatomy teaches us that the spinal cord affords an example of a suspended system of nerves resting on a fluid contained in a swung fibrous tube. Place, therefore, your patient on a water- or air-cushion in one of these hammocks, and sling your hammock as near the window as convenient; then whatever little fresh air, light, sunshine, and rest can be gained in a rookery will be utilised; and, should an instrument of support be considered supplementary, further deformity is prevented during the time for carrying out mechanical detail. The patient's friends constantly pester surgeons with remarks on the deformity. Truly it is an index to the extent of bone dilapidation; but it need not occupy your thought any more than telegraphic engineers repairing a subterranean cable would regard the necessary excavations.

For the easy removal of goods, the first and principal aim of the carrier is to sling them. Observers are struck by the facility and steadiness with which packages are removed from place to place by means of a crane; e.g., in a ship's hold or at a railway goods-shed. I have lately introduced these hammocks to the profession for the transit of invalids by rail, because the conveyance of injured persons has been far too much left to chance, and no practical steps have been taken to remedy an inconvenience of daily occurrence. Let me direct your attention to this modified stretcher, on which is slung a small hammock. This apparatus is easily carried by two men, and is intended not only for exercising patients in the open air, but also for conveying invalids to or from a railway station, so that the patient does not quit the hammock, and consequently all changing is unnecessary. The three patients who have been conveyed from Westminster to Margate, Ringwood, and Bournemouth respectively, in hammocks by rail, have all expressed their great satisfaction; and I can personally bear witness to their testimony. With regard to the further use of hammocks, let me strongly urge that one, at any rate, should be kept at every railway station ; collisions, accidents, and vivisection in various forms, are terms familiar as " household words" to railway directors ; small provision is made by them for the transit of the wounded; in any grave accident, a telegram could thus shortly produce a sufficient supply of swingbeds.

In the North of Devon, I know of men with fractured legs and strangulated herniæ having been placed in a cart on a bundle of straw, and slowly conveyed sixteen miles to the Exeter Hospital. Surely this procedure is not calculated to ensure the recovery of the sufferer! Again, might not a mother's anxiety be lessened, and co-passengers' comfort be increased, by swinging babies and children during long journeys? My experience tends to prove that children very much enjoy a railway journey until fatigue sets in ; their having no suitable means of reclining transforms them into intolerable bores. Are we not more to blame than the children in not anticipating the inevitable? In con. clusion, there are some "travelling larders and wine-collars" who tel 1 surgeons that a good railway jolting is to be approved of, because it shakes up their liver; but there are also surgeons who answer that a horrid railway jolting is to be disapproved of, because it shakes up their nervous system. My sympathies are with the latter; for there is a daily increasing class of educated men who believe that repose in travel is not so much a question of luxury as of necessity.

\section{FOURTH SERIES OF FIFTY CASES OF OVARIOTOMY.}

By T. KEITH, F.R.C.S.,

Surgeon for Ovarian Disease to the Royal Infirmary, Edinburgh.

THE accompanying table gives a fourth series of fifty cases of ovariotomy. The first, second, and third series are reported in the Lancet of September 7th, 1867, August 20th, 1870, and November I6th, 1872. There have been fewer operations than in former years; but I have reason to believe, now that ovariotomy has become a comparatively common operation, that the more severe cases of the disease only come to me. During this period I have also been able to diagnose and cure by a single tapping four cases of serous cyst of the broad ligament. These tumours would some time ago have probably been removed by operation.

The arrangement of this table is the same as the others; only, following the example of Mr. Wells, there has been added the name of the medical attendant of the patient, or of the medical friend who sent me the case. This seems necessary to satisfy the doubts of such men as M. Louis Gallez, who, in his work on Ovariotomy, speaks of my former results in the following terms: "Cette mortalité si minime qu'elle paraît douteuse."

In the first series of fifty cases, there were II deaths.

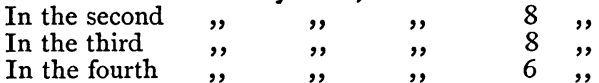

Not included in the above table is the case of the second patient on whom I performed ovariotomy in 1863. After ten years of perfect health, the disease returned in the other ovary. Thinking that she was now too old for operation-she was nearly seventy years of age-she concealed her condition till she could go on no longer. When I saw her last year with the late Dr. Thomson of Dalkeith, she was very infirm, and some relief was given by tapping the largest cyst, for there was much solid left. Soon after this, one of the cysts gave way, and she became very ill. As a matter of course, ovariotomy was again urged upon her, and willingly agreed to. She recovered perfectly, and is now quite well, though I have seldom had a more severe operation. There were extensive parietal, omental, and pelvic adhesions; and there was much adherent intestine. Large dilated veins in the remains of the old pedicle gave rise to troublesome hæmorrhage.

In two cases, ovariotomy was not completed. The first was that of a young lady whom I had seen so far back as 1866 . The cyst was of moderate size, and its growth had been slow; but even then the opinion given to her friends was, that its connections in the pelvis were such that operation was impossible. She came to me always in December, on her way to Hastings, where she passed the winter. Every year added to the doubts as to the possibility of relief by operation. The cyst was looked upon as one of those that had adhered at an early stage, and in which the adhesions had grown with the growth of the tumour. Year after year, it was a relief when she was able to go South for the winter. Her health was now very good, and she enjoyed life as much as any one. The tumour became more consistent as it grew older, and nothing was to be gained by tapping. At length, the time came when the question of interference had to be definitely faced. The strength continued good, but she had to be carried up and down stairs. On her way home for the last time, I requested her, as I had often done before, to consult the authorities in London. There the opinions given were, that there were no unusual local difficulties, and that her case was a fair average one, or rather a favourable one, for operation. Fortified by this opinion, the operation was undertaken. The cyst was incorporated with the wall in front; it was opened freely, and carefully cleaned out of all its contents, which consisted of masses of old fibrine like damp earth. After two hours' deliberate dissection, ending in a tissue of cartilaginous hardness, all attempts to complete the operation failed; the portions of cyst-wall separated were cut away, and

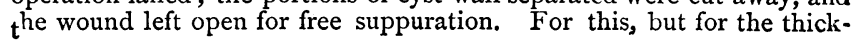


ness of the almost cartilaginous adhesions, the case seemed a fair one. Care had been taken not to injure the bladder, which was known to be drawn upwards far above the pubes; and the abdominal cavity had not been opened into, except towards the end, to satisfy the doubts of some of my friends, when I made a small opening above the umbilicus, and then immediately closed it by catgut ligatures. In this case, I persevered to the uttermost, for I had succeeded in a precisely similar one (No. 1 75). They were both cases of inflamed cyst of the broad ligament, adherent at an early stage, and pushing before them the contents of the abdomen as they grew. Dissection was necessary in both, and in the successful case part of the peritoneal coat was here and there left ; and, as the vessels of a cyst of the broad ligament lie between the layers, the troublesome hæmorrhage that happened in both during the dissection was easily accounted for. At a future time, I shall return to these cases, with others of inflamed broad ligament-cysts. The result of the attempt to cure this case by suppuration ended in a failure. For three weeks, everything promised well ; and just as all felt sure of a favourable termination, and while the patient was laying plans for the future, sudden septicæmia came on, and proved fatal at the end of four weeks. Nearly the last fragments of the cyst had exfoliated, and many large sloughs had been removed during the last week. The surrounding old adhesions were in some places upwards of an inch in thickness, and the contents of the pelvis were so imbedded in this thickened tissue as to be scarcely recognisable.

Table of Fifty Cases of Ovariotomy.

\begin{tabular}{|c|c|c|c|c|c|}
\hline No. & Medical Attendant. & Date. & Age. & Adhesions, etc. & Result. \\
\hline $\begin{array}{l}151 \\
152 \\
153 \\
154 \\
155 \\
156 \\
157 \\
158 \\
159 \\
160 \\
161 \\
162 \\
163 \\
164 \\
165 \\
166 \\
167 \\
168 \\
169 \\
170 \\
171 \\
172 \\
173 \\
174 \\
175 \\
176 \\
177 \\
178 \\
179 \\
180 \\
181 \\
182 \\
183 \\
184 \\
185 \\
186 \\
187 \\
188 \\
189 \\
190 \\
191 \\
192 \\
193 \\
194 \\
195 \\
196 \\
197 \\
198 \\
199 \\
200 \\
\end{array}$ & $\begin{array}{l}\text { Dr. Logie, Kirkwall } \\
\text { Dr. Hardie } \\
\text { Dr. Stewart, Hexham } \\
\text { Dr. Gordon } \\
\text { Dr. Campbell, Montreal } \\
\text { Dr. Black } \\
\text { Dr. Simpson, Marykirk } \\
\text { Dr. James Sidey } \\
\text { Dr. Johnston, Stirling } \\
\text { Dr. Wallace, Parsonstown } \\
\text { Mr. Tuthill } \\
\text { Dr. James Simson } \\
\text { Dr. M. Duncan } \\
\text { Dr. Peddie } \\
\text { Dr. Hemming, Kimbolton } \\
\text { Dr. Maclagan, Berwick } \\
\text { Dr. Howden, Haddington } \\
\text { Dr. Kidd, Alyth } \\
\text { Dr. Muir, Moniaive } \\
\text { Dr. G. Keith } \\
\text { Dr. Lyall, Leven } \\
\text { Dr. McCulloch, Dumfries } \\
\text { Dr. Hoggan, Thornhill } \\
\text { Dr. Miller, Londonderry } \\
\text { Dr. George Balfour } \\
\text { Dr. Dickson, Falkland] } \\
\text { Dr. Wilson } \\
\text { Dr. M. Duncan } \\
\text { Dr. Menzies } \\
\text { Dr. McGillivray, Oban } \\
\text { Dr. Bernard, Londonderry } \\
\text { Dr. Young, Kirkcaldy } \\
\text { Dr. Filson, Portaferry } \\
\text { Dr. Charles Bell } \\
\text { Dr. Barkus, Gateshead } \\
\text { Dr. Perry, Glasgow } \\
\text { Dr. Ziegler } \\
\text { Dr. Thorne, Newcastle } \\
\text { Dr. M. Duncan } \\
\text { Dr. Dickson } \\
\text { Dr. Strahan, Dollar } \\
\text { Dr. Miller, Londonderry } \\
\text { Dr. McFadyen, Alva } \\
\text { Dr. Mortimer, Turriff } \\
\text { Dr. Kidd, Dublin } \\
\text { Dr. Graham, Weir } \\
\text { Dr. Barkus, Gateshead } \\
\text { Dr. Pirrie, Dundee } \\
\text { Dr. Perry, Glasgow } \\
\text { Dr. M. Duncan } \\
\end{array}$ & 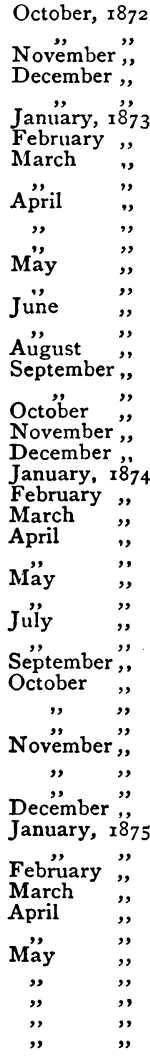 & $\begin{array}{l}31 \\
40 \\
21 \\
67 \\
20 \\
53 \\
29 \\
63 \\
24 \\
20 \\
24 \\
24 \\
45 \\
24 \\
24 \\
53 \\
57 \\
36 \\
24 \\
27 \\
27 \\
24 \\
23 \\
26 \\
26 \\
65 \\
36 \\
36 \\
51 \\
46 \\
29 \\
50 \\
44 \\
25 \\
31 \\
52 \\
60 \\
23 \\
44 \\
34 \\
28 \\
40 \\
30 \\
30 \\
22 \\
50 \\
34 \\
36 \\
39 \\
22\end{array}$ & 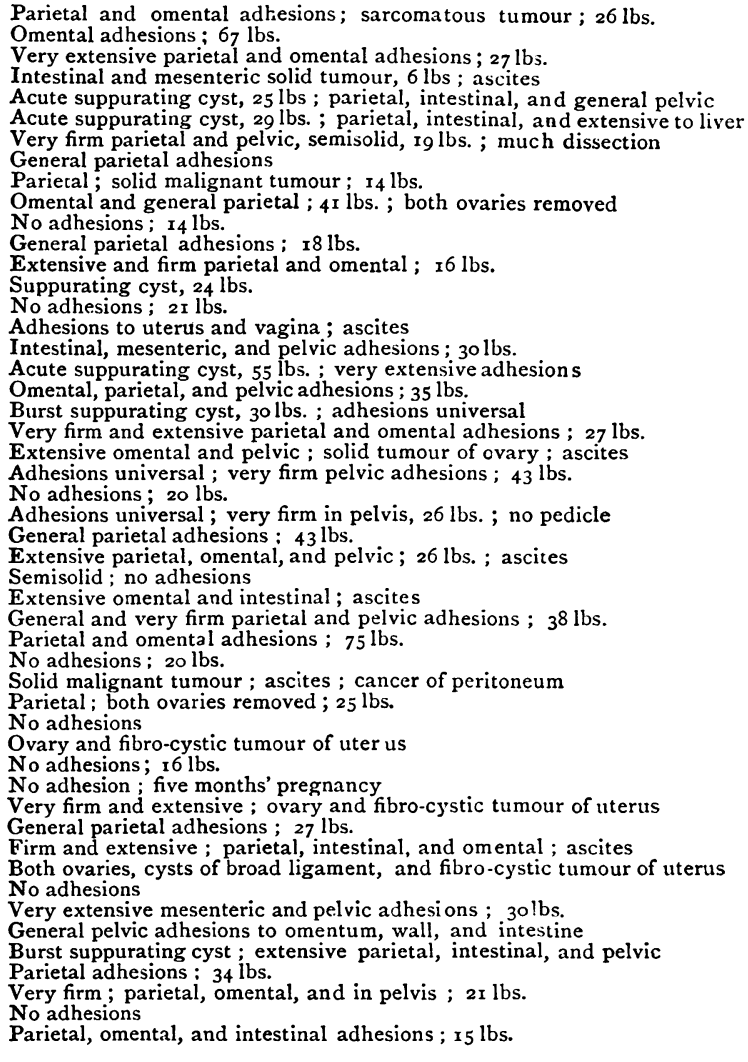 & $\begin{array}{l}\text { Recovered } \\
\text { Recovered } \\
\text { Recovered } \\
\text { Recovered } \\
\text { Recovered } \\
\text { Died } \\
\text { Recovered } \\
\text { Recovered } \\
\text { Died } \\
\text { Recovered } \\
\text { Recovered } \\
\text { Recovered } \\
\text { Recovered } \\
\text { Recovered } \\
\text { Recovered } \\
\text { Recovered } \\
\text { Recovered } \\
\text { Recovered } \\
\text { Recovered } \\
\text { Recovered } \\
\text { Recovered } \\
\text { Recovered } \\
\text { Died } \\
\text { Recovered } \\
\text { Recovered } \\
\text { Recovered } \\
\text { Recovered } \\
\text { Recovered } \\
\text { Recovered } \\
\text { Recovered } \\
\text { Recovered } \\
\text { Recovered } \\
\text { Died } \\
\text { Recovered } \\
\text { Recovered } \\
\text { Recovered } \\
\text { Recovered } \\
\text { Recovered } \\
\text { Recovered } \\
\text { Recovered } \\
\text { Recovered } \\
\text { Recovered } \\
\text { Recovered } \\
\text { Died } \\
\text { Recovered } \\
\text { Recovered } \\
\text { Recovered } \\
\text { Recovered } \\
\text { Recovered } \\
\text { Died }\end{array}$ \\
\hline
\end{tabular}

The second incomplete operation was that of a stout strong looking woman, 53 years of age, sent to me by Dr. Fiddes of Aberdeen. She had been tapped four or five times. The abdomen was rather large and tense when she came, and, though pelvic adhesions were expected, there seemed nothing in her general condition to forbid operation. In this she was as anxious as she was averse to another tapping. On opening the abdomen, a quantity of dark ascitic fluid escaped, and an ovarian tumour came into view, reaching to the umbilicus. Several cysts were punctured and emptied. It was then seen that adhesion all round to the brim of the pelvis was so intimate, that no attempt was made to do more, especially as the appearances of some folds of adherent intestine were suspicious. The collapsed cyst-walls were secured in the wound by Rochale's serre-nœud, and a drainage-tube was left in. She died three days afterwards, and every organ in the abdomen was found to be loaded with cancerous deposits. A preliminary tapping would certainly in this case have prevented any further interference.

In the six fatal cases, the cause of death was septicæmia. The first was a case of acute suppurating cyst with pyæmic fever. It seemed a hopeless undertaking, but equally hopeless like cases of suppurating cysts had recovered. In the second and fourth, the tumours were malignant. In both there was red serum in the abdomen, and both had fluid in the pleura at the time of operation. Of the other thre cases, in two the operations were very severe, lasting nearly three hours in the one and upwards of two hours in the other. This latter was a badly constitutioned woman, and had suffered from acute kidneyaffection, with convulsions. One was drained, the other was not. Earlier operation might have saved both. In the last fatal case, the patient was perfectly well till the sixth day, and recovery seemed sure. In a few hours, the temperature rose to $106 \mathrm{deg}$., the pulse to 170 , and she died four days after.

Farther experience has satisfied me of the value of the actual cautery in the treatment of the pedicle, and I am coming to the conclusion that it is the best of all the intraperitoneal methods for securing the pedicle. At first, I was prejudiced against this method, and only used it in the worst cases, where the clamp could not be employed. It has had from me a very severe trial, and, when the numbers are larger, shall publish the whole of the cases in detail. This method, as is well known, was introduced by the late Mr. Baker Brown, and, after trying all sorts of improved clamps, I have gone back to the simple rougl tool so successfully used by him.

Sulphuric ether has been given in all the cases. 